\title{
Understanding and Perceptions of Skin Donation and Skin Banking among Health Care Professionals - Tertiary Care Centre in Eastern India
}

\author{
Mrs. Serma Subathra Arunachalam ${ }^{1}$, Dr. Asha P Shetty ${ }^{2}$, Dr. Sanjay K Giri ${ }^{3}$, Dr. Shankar Shanmugam \\ Rajendran $^{4}$, Mr. HariKrishnan Eswaran ${ }^{5}$ \\ ${ }^{1}$ Tutor /Clinical Instructor, College of Nursing, AIIMS Bhubaneswar, Odisha, India \\ ${ }^{2}$ Prof Cum Principal, College of Nursing, AIIMS, Bhubaneswar, Odisha, India \\ ${ }^{3}$ Asso Prof, Dept of Burns \& Plastic Surgery, AIIMS, Bhubaneswar, Odisha, India \\ ${ }^{4}$ Reader /Associate Professor, College of Nursing, Madras Medical College, Chennai, India \\ ${ }^{5}$ Asst Nursing Superintendent, ESIC, SSH, Sanath Nagar, Hyderabad, Telangana, India
}

\begin{abstract}
Introduction: The skin is our body's most diverse organ. Other organs, such as the kidneys and liver, could be impaired and somehow still function, but the loss of 40percent of someone's skin can be fatal. In developing countries, burns led to the deaths of the majority of people. The study aimed to establish the relationship between medical professionals' awareness and attitudes regarding skin donation and skin banking.

Methods: This cross-sectional survey was conducted at the All India Institute of Medical Sciences, Bhubaneswar, AIIMS, Odisha, between August 2020 to November 2020. A total of 124 health care practitioners from AIIMS, BBSR responded to the survey questions. It is divided into five sections: Social and economic data; Skin donation awareness survey, and skin bank attitude scale. Results: Less than half of health care professionals, $53.74 \%$, reported a lack of awareness of skin donation, and 56.16 per cent said lack of understanding of skin bank. The fair, positive relationship prevailed among skin donation awareness, and then either attitude $(\mathrm{r}=0.36, \mathrm{P}=0.01)$, and a similar relationship existed between skin banking awareness and attitude $(\mathrm{r}=0.32, \mathrm{P}=0.01)$. According to the report's findings, having a clear understanding of skin donation and skin banking leads to positive behaviours.

Conclusion: In this review, health care professionals' awareness of skin donation and skin banking is average. Hospital and nursing administrators should be actively involved in education programmes to enhance nurses' education and increase awareness about skin donation and skin banking.
\end{abstract}

KEYWORDS: Awareness, Attitude, Health care professionals, Skin donation, Skin Bank

\section{INTRODUCTION}

Our body's skin is a multi-functional organ. It acts as a conduit against micro-organisms entering our bodies. By wrapping around the body, it generates a robust effect. [1] It probably accounts for $15 \%$ of our body mass. Skin reinstates it every 28 days. Thirty thousand dead cells were shed each minute from our skin. .[2] Other organs, such as the liver and kidney, can withstand more than $60 \%$ damage, but losing $40 \%$ of one's skin can be fatal unless the tissue is replaced. [3] Cylinder explosions, flares, road traffic collisions, acid spillages, cuts, scrapes, chronic unhealed ulcers, and decubitus ulcers, among several other things, cause serious harm. It must have been reported that, after road accidents, the second-largest categorisation of injuries. [4] Severe burn injuries necessitated skin grafting, as did deep gashes and fractures caused by accidents. [5] No blood group, age, or colour matching is needed because everyone's skin is conceivable. Both people will benefit from skin donation[6]. The human body is a complex machine that necessitates repairing and replacing faulty components for it to operate appropriately. Spare parts for the human body are not accessible, unlike machines. Instead, with individual consent from either the living donor or the deceased's family member, human tissue from the dead and potentially dead may be donated to the needy. [7] Burns ruined the lives of the majority of people in developing countries. The demand for skin tissue varies for the treatment phase depending on the degree of burn injury, the lethal zone. [8] Approximately one lakh to 1.5 lakh people in India are disabled, requiring several interventions and rehab. [9] Alternative treatment strategies of skin repair also arisen, which can be permanent or temporary. Consider the number of instances that need 


\section{International Journal of Current Science Research and Review}

ISSN: 2581-8341

Volume 04 Issue 06 June 2021

DOI: 10.47191/ijcsrr/V4-i6-02, Impact Factor: 5.825

IJCSRR @ 2021

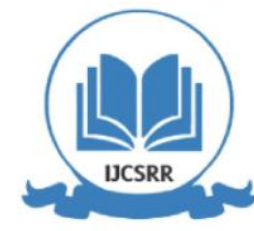

www.ijesrr.org

this therapeutic approach in a developing country like India, skin graft awareness or availability are lacking. [10] Then after meshing of grafts, the skin in a massive burn and traumatic patient is inadequate. The skin which will be used would be obtained from living, brain dead, and deceased donors. A cadaveric skin graft may be a good option at the moment. [11] When epidermal tissue are harvested from cadavers, skin banking facilities are required for preservation and prospective use. Skin is harvested from donors within 6 hours after death, processed in glycerol, and afterwards transferred to a skin banks. Result shows, the integument is preserved in a bank for further use. [12]

This study aimed to find out how much health care professionals knew regarding skin donation and skin banking and how they thought about it. The study's primary goal is as follows:

1. There is a correlation between healthcare professionals' perceptions and their awareness of skin donation and skin banking.

2. There is a difference amongst healthcare professionals' perceptions of skin donation and skin banking and their awareness of the protocols.

\section{SIGNIFICANCE OF THE STUDY}

Human skin grafts are indeed the gold standard for treating burns injury and non-healing wounds in the long run. [13] The acquisition of skin from a living donor generally requires fulfilling a set of questions, including the operative protocol. [14] The notable benefit of cadaveric skin donation include ultimate control of protein and water loss from wounds, a reversal of metabolic function, better dietary level, wound care, and instant pain relief, which all contribute to the sufferer's well-being. [8] [15] Every year, almost 7 million people in India suffer from severe burns, involving 1.4 lakh fatalities and 2.4 lakh people suffering disabilities. Workplace safety, on either side, has led to the reduction in electrical and thermal burn injuries in high-income countries. Every year, one million cases of burn injury were reported in India, with women and children comprising about 80\% of the overall.[16] The second common injury is burns, $10 \%$ of injuries are life-threatening, and 50\% of victims died due to the injuries. [17] Skin banking services have been available in India since April 24, 2000, in Mumbai. The prime motive for establishing a tissue bank was to address the high mortality rate caused by various types of injuries, accidents, trauma, non-healing ulcers, aesthetic surgery, and augmentation procedures. The autologous split skin graft is the most acceptable aid for lost skin. [11] Health care professionals are influential in building close contact with patients and families as representing pivotal personnel in organ donation, especially skin donation. Acting as a liaison between the patient and family of a potential or departed donor. [18] It is noticed that potential donor has a focused grasp of nature and the transplant process. Undoubtedly, nurse' and medics' empathetic approaches to patients and families have such a considerable role in promoting skin donation and the decision to bequeath. [19] Irrespective of the reports, higher-level health professionals had fewer qualms about organ donation, including skin donation. Their beliefs, family perspective, and emotions resulting in the death of the relative do influence them. [20] Raising awareness of skin donation can boost views amongst health professionals also influence public opinion on organ donation and owing. [21] As per a recent study in Iran, a nurse coordinator plays a vital role in counselling family more about the value of other donating organs [22]. The current study analyst highlighted the limitations on advocating tissue donation and skin banking amongst healthcare professionals. Researchers tried to determine health providers' level of awareness on skin donation and skin banking to improve public understanding of skin donation.

\section{RESEARCH METHODOLOGY.}

\subsection{Materials}

This cross-sectional poll was performed at the All India Institute of Medical Sciences in Bhubaneswar, Odisha, India, from August 2020 to November 2020. The study population comprised 124 health care professionals, such as 45 doctors, 56 nurses, and 23 technicians from a tertiary hospital. At AIIMS BBSR, health care providers employed in various surgical areas, a medical unit, trauma and emergency regions, several operating rooms, ICU and dialysis units.

\subsection{Inclusion Criteria - Willingness to Participate}

\subsection{Sampling technique}

Study participants were recruited based on their availability ,using a stratified random sampling approach. The following formula was used to determine the sampling frame: $\left(n=z^{2} P q / d^{2}\right)$ where $(z=1.96)$, and $(n)$ is the anticipated number of participants with one group while " $p$ " is the predicted percentage distribution from one of two potential values of a dichotomous variable in the population. The degree of confidence is 1.96, and the desired range of confidence level is "d." At the two-way use of the contingency table, the 


\section{International Journal of Current Science Research and Review}

ISSN: 2581-8341

Volume 04 Issue 06 June 2021

DOI: 10.47191/ijcsrr/V4-i6-02, Impact Factor: 5.825

IJCSRR@ 2021

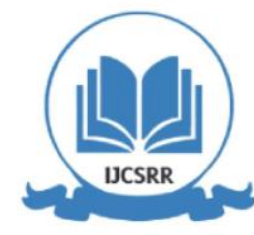

www.ijesrr.org

study's anticipated power is 80 per cent. As per prior studies," in south India amongst these city dwellers on organ donation,[23] that necessary sample size, with a per cent of the confidence interval of $\pm 10 \%$ sample size as per the formula, approximately 116 individuals. At the end of data collection, 124 health professionals responded to the survey and were included in data gathering.

\subsection{Pilot study}

The goal of this pilot test has been to put into action a survey tool developed, to test healthcare providers' awareness and attitude on skin donation and skin banking at AIIMS and BBSR. The questionnaire was validated, and the estimated reliability was established. After conducting an extensive literature review, the researcher developed the survey previous research and guidelines. [3][13][24][8][2][25] The questionnaire was organised into five parts. The first section assessed demographics, whereas the second and third blocks rated understanding tissue donating and skin banking. The 4th and 5th blocks subsequently investigated health care providers' attitude towards tissue donation/skin banking. For the feasibility study, the questionnaire's content and face validity were tested prior to data collection. A panel of $(n=7)$ experts completed validity testing, which also included five cosmetic surgeons, one Dermatologist, as well as a nursing expert. The expert was asked to review each survey question and review the items for readability and cultural competency. Each item was rated as Very Relevant, Relevant, Irrelevant, or Very Unimportant to the conceptualisation of a theoretical construct. The question was then revised based on feedback from the expert panel. The predicted validity index value was 97.5 cent. Incorporating are some suggested changes, consent form was added at the beginning of the survey and clearly explained to a study's participants, including participation is voluntary. The information transferred to users between June 2020 to July 2020 on the impact of the lockout prompted with Covid -19. The poll was earlier performed among 25 health professionals, comprising Alumni of AIIMS BBSR working at different hospitals and healthcare providers from ESIC, SSH, Hyderabad, and Telangana State. A pre-test and post-test were conducted at 10-day interval to measure the tool's reliability, feasibility, and internal consistency. Overall test-retest reliability of skin donation knowledge was estimated $(r=0.82, p=0.001)$. The split-half consistency test was conducted to assess the attitude scale for skin donation and skin bank $(\mathrm{r}=0.84, \mathrm{p}=0.001)$. Overall Spearman-Brown correlation coefficient reliability values was $(\mathrm{r}=0.74, \mathrm{p}=0.001)$ and $(\mathrm{r}=0.72, \mathrm{p}=0.001)$.

\subsection{Study questionnaire}

A self-administered, structured questionnaire is used to collect data from respondents. Sec A - assessed demographics comprised 11 items: age, gender, religion, healthcare professional, the field of work, education, awareness, source of news about skin donation, and vowed organ donation. Fifteen items and intended to explore a knowledge survey questionnaire skin donation and ten things related to skin banking knowledge, closed-ended questions offered with options choose in every item. Each move was recorded as one for a correct response and did not result in a zero score. In testing awareness on skin donation and skin banking, study participants who scored $80 \%$ or above were deemed to have a good understanding, 51 per cent to 79 per cent are rated relatively acceptable, and less than $50 \%$ were categorised as having inadequate knowledge. The fourth and fifth blocks measured health care professionals' views on skin donating and skin bank, with $(>51 \%)$ indicating a positive perception as well as $(<50 \%)$ meaning an undesirable one. The study participants were approached on their workplaces, and the Google link was sent via Android devices.

\subsection{Ethical and administrative issues}

The AIIMS Institute Ethics Committee in Bhubaneswar, Odisha, has accepted the study, with reference number T/IM/NF/Nursing/20/63. Confirmed informed consent: After recruiting respondents, the investigator bided and affirmed their right to quit the poll without penalties, so their participation was voluntary.

\subsection{Statistical Analysis}

Data collected via Google forms were retrieved, encoded in MS Office Excel, then analysed using SPSS 22.0. The obtained data were analysed to use both descriptive and inferential tests. The descriptive statistics also included running frequencies and percentages. Karl Person correlation was used to estimate the relationship between knowledge information and perspective on skin donation and skin banking; the chi-square analysis was used to identify associations on demographics between computed knowledge and attitude scores. The statistical test was two-sided, and a P-value of.01 was deemed significant. These results are exposed to a mandatory test that is used to check for a $5 \%$ considerable relationship. 


\section{International Journal of Current Science Research and Review}

ISSN: 2581-8341

Volume 04 Issue 06 June 2021

DOI: 10.47191/ijesrr/V4-i6-02, Impact Factor: 5.825

\section{RESULTS}

\section{IV .1. Participants Demographics}

Table 1- depicts the socio-demographic profile of the sample. The sample covered a number of 124 individuals, 84 of which were men (67.74 per cent) and Forty of whom have been females (32.26 per cent). Half of the survey participants (50\%) are degrees, while only 2(1.6\%) had Diploma professional training.

Table 1. Demographic characteristics of study participants

\begin{tabular}{|c|c|c|c|}
\hline \multicolumn{2}{|l|}{ Demographic Variable } & Health Care professionals (f) & $\%$ \\
\hline \multirow[t]{4}{*}{ Age } & $21-25$ years & 46 & $37.10 \%$ \\
\hline & 26-30Years & 54 & $43.55 \%$ \\
\hline & $31-35$ Years & 14 & $11.29 \%$ \\
\hline & 36- 40 years & 10 & $8.06 \%$ \\
\hline \multirow[t]{2}{*}{ Gender } & Male & 84 & $67.74 \%$ \\
\hline & Female & 40 & $32.26 \%$ \\
\hline \multirow[t]{5}{*}{ Educational Status } & Diploma & 2 & $1.61 \%$ \\
\hline & Doctoral & 1 & $0.81 \%$ \\
\hline & Graduate & 62 & $50 \%$ \\
\hline & Inter college & 2 & $1.61 \%$ \\
\hline & Post Graduate & 57 & $45.97 \%$ \\
\hline \multirow{3}{*}{$\begin{array}{l}\text { Health care professionals } \\
\text { as a }\end{array}$} & Doctor & 45 & $36.29 \%$ \\
\hline & Nurse & 56 & $45.16 \%$ \\
\hline & Technician & 23 & $18.55 \%$ \\
\hline \multirow[t]{6}{*}{ Religion } & Atheist & 4 & $3.23 \%$ \\
\hline & Buddhist & 2 & $1.61 \%$ \\
\hline & Christian & 17 & $13.71 \%$ \\
\hline & Hindu & 94 & $75.81 \%$ \\
\hline & Jain & 2 & $1.61 \%$ \\
\hline & Muslim & 5 & $4.03 \%$ \\
\hline \multirow[t]{6}{*}{ Aware of skin donation } & $\begin{array}{l}\text { Awareness } \\
\text { programme }\end{array}$ & 9 & $7.26 \%$ \\
\hline & News Paper & 7 & $5.65 \%$ \\
\hline & Not aware & 38 & $30.65 \%$ \\
\hline & Posters & 2 & $1.61 \%$ \\
\hline & Social Media & 64 & $51.61 \%$ \\
\hline & TV & 4 & $3.22 \%$ \\
\hline \multirow[t]{6}{*}{$\begin{array}{lll}\text { Heard about } & \text { Skin } \\
\text { banking } & & \end{array}$} & $\begin{array}{l}\text { Awareness } \\
\text { programme }\end{array}$ & 10 & $8.06 \%$ \\
\hline & News Paper & 8 & $6.45 \%$ \\
\hline & Not aware & 54 & $43.55 \%$ \\
\hline & Posters & 2 & $1.61 \%$ \\
\hline & Social Media & 46 & $37.10 \%$ \\
\hline & TV & 4 & $3.23 \%$ \\
\hline \multirow{2}{*}{$\begin{array}{l}\text { Have you pledged for } \\
\text { Skin banking }\end{array}$} & Yes & 39 & $31.45 \%$ \\
\hline & No & 85 & $68.55 \%$ \\
\hline \multirow[t]{2}{*}{$\mathrm{H} / \mathrm{O}$ of Skin donation } & Yes & 1 & $0.81 \%$ \\
\hline & No & 123 & $99.19 \%$ \\
\hline
\end{tabular}




\section{International Journal of Current Science Research and Review}

ISSN: 2581-8341

Volume 04 Issue 06 June 2021

DOI: 10.47191/ijcsrr/V4-i6-02, Impact Factor: 5.825

Figure 1: depicts the dispersion of care providers involved in the study. Nearly half of them, 43,55 \% respondents, are between the age of 26 years to 30years, with almost 75.81 per cent of them being Hindus. When asked if they had pledged for organ donation, only $31.45 \%$ said yeah, of course. Half of the subjects, 51.61 per cent, were just informed of skin donating via mass media. The vast majority reported no prior family history of tissue donation in $99.19 \%$ of the health care professionals.

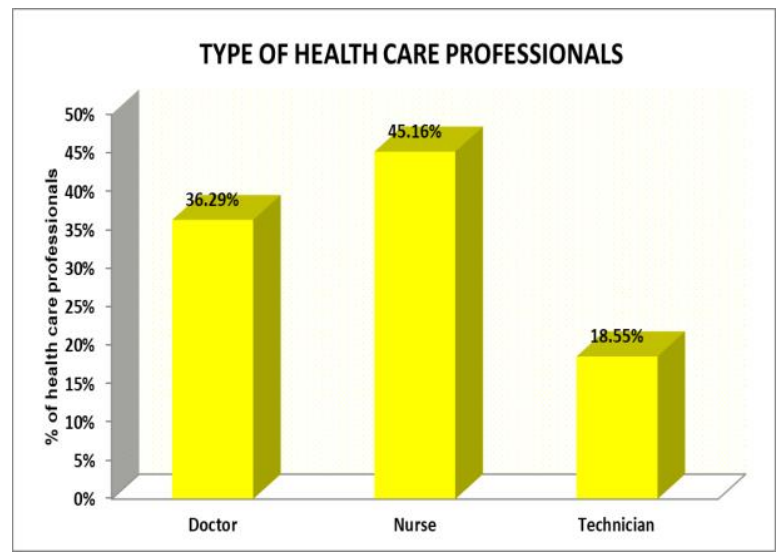

Fig 2 : Sources of Awareness on Skin donation

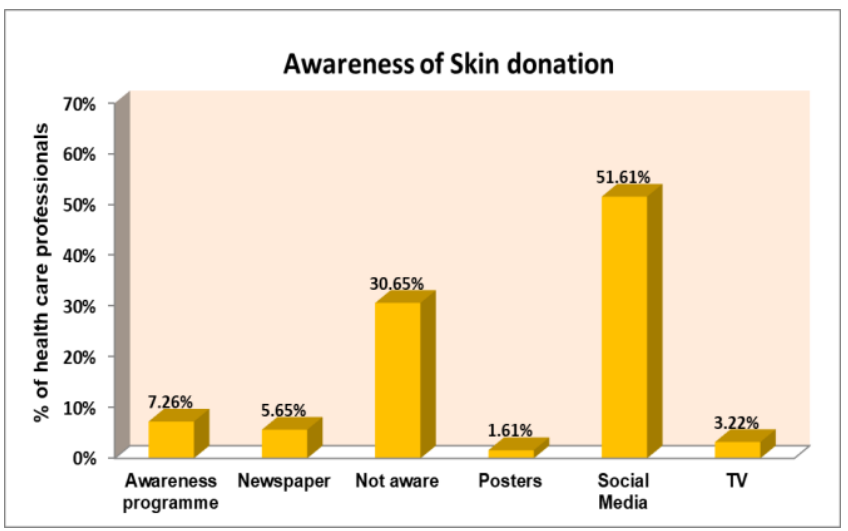

Figure 3 shows that $64.62 \%$ reported having a moderately adequate level of knowledge on skin donation (Mean \& Sd -7.65 \pm 2.49 .)

Fig 3: Level of Awareness about Skin donation






\section{International Journal of Current Science Research and Review}

ISSN: 2581-8341

Volume 04 Issue 06 June 2021

DOI: 10.47191/ijcsrr/V4-i6-02, Impact Factor: 5.825

IJCSRR @ 2021

www.ijjcsrr.org

Fig 4 : Level of Awareness about Skin Bank

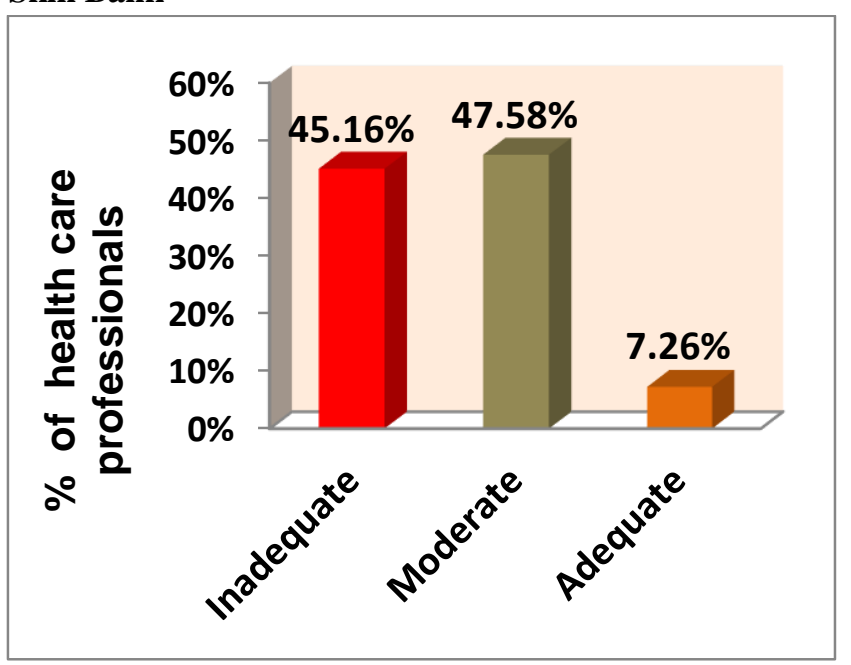

Table 2. Mean Percentage and Standard deviation of level of attitude on skin donation and skin banking $(\mathrm{n}=124)$

\begin{tabular}{|l|l|l|l|l|l|}
\hline $\begin{array}{l}\text { Attitude on Skin Donation } \\
\text { Mean \& Sd - 29.41 } \pm \text { 4.45 }\end{array}$ & $\begin{array}{l}\text { Attitude on Skin banking } \\
\text { Mean \& Sd- 21.25 } \pm 2.82\end{array}$ \\
\hline Skin Donation & $\begin{array}{l}\text { Health care } \\
\text { professionals (n) }\end{array}$ & $\%$ & Skin Banking & $\begin{array}{l}\text { Health } \\
\text { professionals (n) }\end{array}$ & $\begin{array}{l}\text { care } \\
\text { Unfavourable Attitude }\end{array}$ \\
\hline Favourable Attitude & 22 & $17.74 \%$ & $\begin{array}{l}\text { Unfavourable } \\
\text { Attitude }\end{array}$ & 20 & $16.12 \%$ \\
\hline
\end{tabular}

Fig 3: shown only $47.58 \%$ reported having a relatively sufficient level of understanding of skin bank ( Mean $\&$ Sd-3.75 \pm 1.81$)$ as well as its facility and benefits. About half, 53.74 per cent of healthcare workers reported inadequate information on skin donation, whereas 45.16 per cent reported insufficient awareness of organ donation.

The majority of 83.06 per cent of healthcare professionals were informed that skin tissue was harvested from the legs, thigh, and posterior body sites of cadaveric and live donors. Just a minimum of $19.45 \%$ of volunteers who've been aware of donors living with sexually transmitted infections wouldn't become a donor. The youth of today, aged 21 to 25 years 84.78 per cent, 26-30 years 77.78 per cent, 31-35 years 85.71 per cent, and 36-40 years (90 per cent, were more receptive to skin donation. Additionally, prior knowledge on skin donation and skin banking seems to impact offerings and transplant rates positively. A vast majority of 82.26 per cent of respondents agreed and had a more favourable attitude on skin donation, and 83.88 per cent for skin banking. The majority of 84 respondents 67.74 percent believed that skin donation would cause a delay and end up making funeral rites impractical. Only about one-third (20.13 per cent) of those polled concurred that they'd instead donate their skin and encourage their family and friends when they're still living.

\section{IV: 4 Predictors of Knowledge and Attitude toward skin donation and skin banking}

The mean knowledge score for skin donation is 7.65(SD, 2.49) (Range 0-15), whilst skin banking was 3.75(SD, 1.81) (Range 0-10). The statistically significant difference in knowledge scores on skin donation and skin banking between three groups formed based on the study subjects, and their professions were Nurses, Doctors, and technicians $((\chi 2=18.19, \mathrm{df}=4, P=0.001)$ and $(\chi 2=13.13, \mathrm{df}=$ 4, $P=0.001)$. Males have just a significant association with knowledge on skin donation and skin banking at the $((\chi 2=7.42, \mathrm{df}=2$, 


\section{International Journal of Current Science Research and Review}

ISSN: 2581-8341

Volume 04 Issue 06 June 2021

DOI: 10.47191/ijesrr/V4-i6-02, Impact Factor: 5.825

$P=0.02)$ level and $((\chi 2=7.17, \mathrm{df}=0.03, P=0.03)$ level, so there is a significant relationship between participants who pledged for organ donation and their knowledge on skin donation and skin banking at the $(\chi 2=6.88, \mathrm{df}=2, P=0.03)$ and $(\chi 2=10.06, \mathrm{df}=2, P=$ $0.01)$.

Tables 3 and 4 There was even a substantial difference in attitudes toward skin donation and skin banking amongst participants gender-based health professional and vowed organ donation. The mean attitude score for skin donation was 29.41 (SD,4.45) (Range 1-40), whereas the average attitude score for skin banking was 21.25 (SD,2.82) (Range1-32). There's no statistical difference in age, education, religion, awareness, or family history of skin donation between skin donation and skin bank views of healthcare professionals.

Table 3 :Shown association between knowledge on skin donation and skin banking $(n=124)$

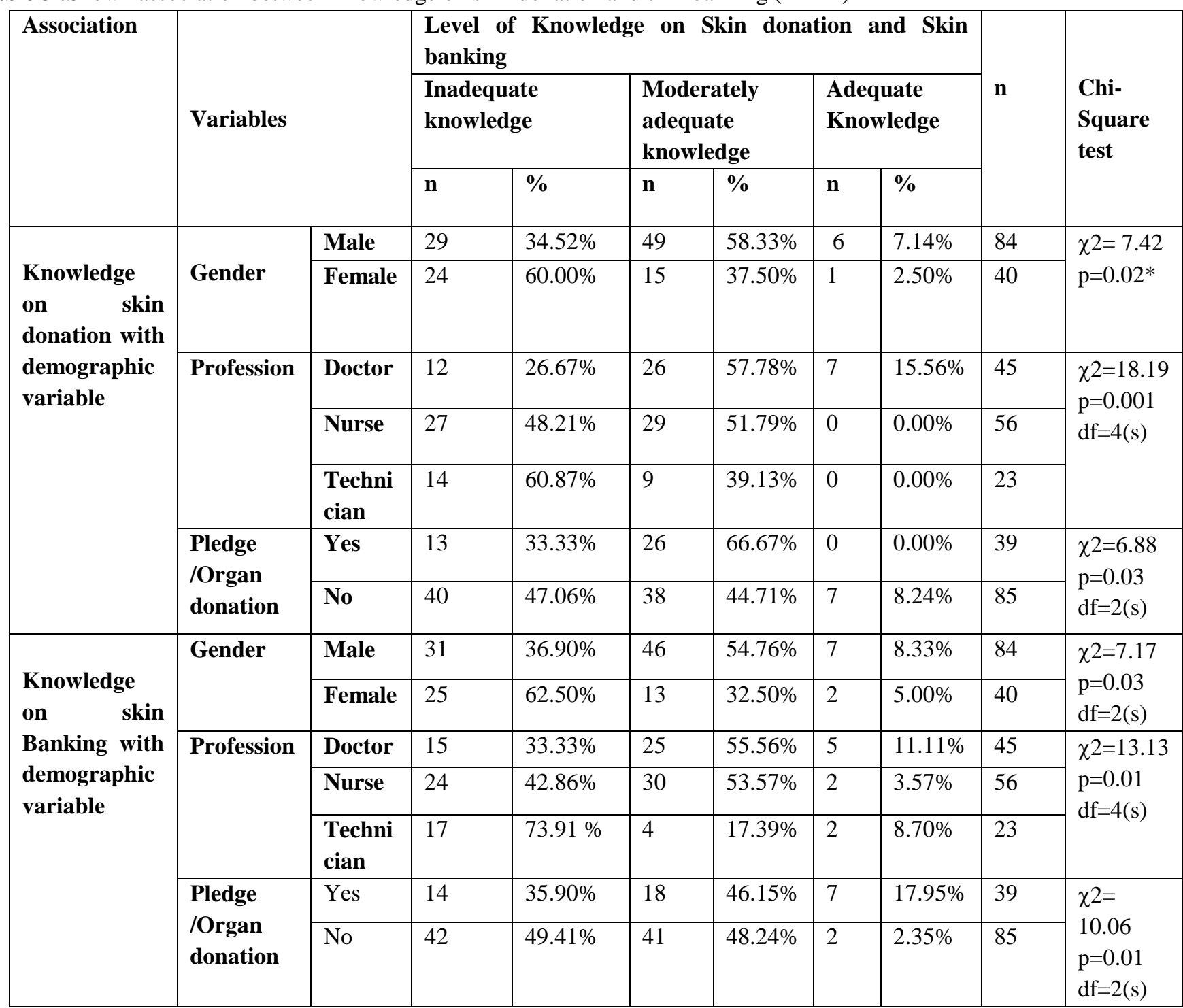




\section{International Journal of Current Science Research and Review}

ISSN: 2581-8341

Volume 04 Issue 06 June 2021

DOI: 10.47191/ijesrr/V4-i6-02, Impact Factor: 5.825

IJCSRR@ 2021

www.ijjesrr.org

Table 4. shown the association between attitude on skin donation and skin banking with demographic characteristics $(\mathrm{n}=124)$

\begin{tabular}{|c|c|c|c|c|c|c|c|c|}
\hline \multirow[t]{3}{*}{ Association } & \multirow{3}{*}{\multicolumn{2}{|c|}{ Variable }} & \multicolumn{4}{|c|}{$\begin{array}{l}\text { Attitude on Skin donation and Skin } \\
\text { banking }\end{array}$} & \multirow[t]{3}{*}{$\mathbf{n}$} & \multirow{3}{*}{$\begin{array}{l}\text { Chi-Square } \\
\text { test }\end{array}$} \\
\hline & & & \multicolumn{2}{|c|}{$\begin{array}{l}\text { Un Favourable } \\
\text { attitude }\end{array}$} & \multicolumn{2}{|c|}{$\begin{array}{l}\text { Favourable } \\
\text { attitude }\end{array}$} & & \\
\hline & & & $\mathbf{n}$ & $\%$ & $\mathbf{n}$ & $\%$ & & \\
\hline \multirow{7}{*}{$\begin{array}{l}\text { Attitude on } \\
\text { skin donation } \\
\text { with socio- } \\
\text { demographic } \\
\text { variable }\end{array}$} & \multirow[t]{2}{*}{ Gender } & Male & 11 & $13.09 \%$ & 73 & $86.91 \%$ & 84 & \multirow{2}{*}{$\begin{array}{l}\chi^{2}=3.86 \\
\mathrm{p}=0.05 \\
\mathrm{df}=1\end{array}$} \\
\hline & & Female & 11 & $27.50 \%$ & 29 & $72.50 \%$ & 40 & \\
\hline & \multirow[t]{3}{*}{\begin{tabular}{|l} 
Profession \\
\end{tabular}} & Doctor & 5 & $11.11 \%$ & 40 & $88.89 \%$ & 45 & \multirow{3}{*}{$\begin{array}{l}\chi^{2}=6.04 \\
p=0.05 \\
d f=2\end{array}$} \\
\hline & & Nurse & 9 & $16.7 \%$ & 47 & $83.93 \%$ & 56 & \\
\hline & & Technician & 8 & $34.78 \%$ & 15 & $65.22 \%$ & 23 & \\
\hline & \multirow{2}{*}{$\begin{array}{l}\text { Pledge } \\
\text { /Organ } \\
\text { donation }\end{array}$} & Yes & 3 & $7.69 \%$ & 36 & $92.31 \%$ & 39 & \multirow{2}{*}{$\begin{array}{l}\chi^{2}=3.93 \\
P=0.05 \\
d f=2\end{array}$} \\
\hline & & No & 19 & $22.35 \%$ & 66 & $77.65 \%$ & 85 & \\
\hline \multirow{7}{*}{$\begin{array}{l}\text { Attitude on } \\
\text { skin Banking } \\
\text { with socio- } \\
\text { demographic } \\
\text { variable }\end{array}$} & \multirow[t]{2}{*}{ Gender } & Male & 9 & $10.71 \%$ & 75 & $89.29 \%$ & 84 & \multirow{2}{*}{$\begin{array}{l}\chi^{2}=5.64 \\
P=0.02 \\
d f=1\end{array}$} \\
\hline & & Female & 11 & $27.50 \%$ & 29 & $72.50 \%$ & 40 & \\
\hline & \multirow{3}{*}{ Profession } & Doctor & 3 & $6.67 \%$ & 42 & $93.33 \%$ & 45 & \multirow{3}{*}{$\begin{array}{l}\chi 2=6.58 \\
p=0.04 \\
d f=2\end{array}$} \\
\hline & & Nurse & 10 & $17.85 \%$ & 46 & $82.15 \%$ & 56 & \\
\hline & & Technician & 7 & $30.43 \%$ & 16 & $69.57 \%$ & 23 & \\
\hline & \multirow{2}{*}{$\begin{array}{l}\text { Pledge } \\
\text { /Organ } \\
\text { Donation }\end{array}$} & Yes & 2 & $5.12 \%$ & 37 & $94.88 \%$ & 39 & \multirow{2}{*}{$\begin{array}{l}\chi^{2}=5.09 \\
\mathrm{p}=0.02 \\
\mathrm{df}=2\end{array}$} \\
\hline & & No & 18 & $21.18 \%$ & 67 & $78.82 \%$ & 85 & \\
\hline
\end{tabular}

\subsection{Knowledge and Attitude Correlation}

The scatter diagrams in Figures 5 and 6 revealed a significant positive fair correlation between skin donation $(r=0.36$, $p=0.01)$ and skin banking $(\mathrm{r}=0.32, \mathrm{p}=0.01)$ outcome (knowledge \& attitude). As per the study's findings, having a good understanding of skin donation and skin banking corresponds to positive attitudes among healthcare professionals.

Fig 5 : The scatter diagram illustrates the relationship between awareness and the attitude of Skin donation.

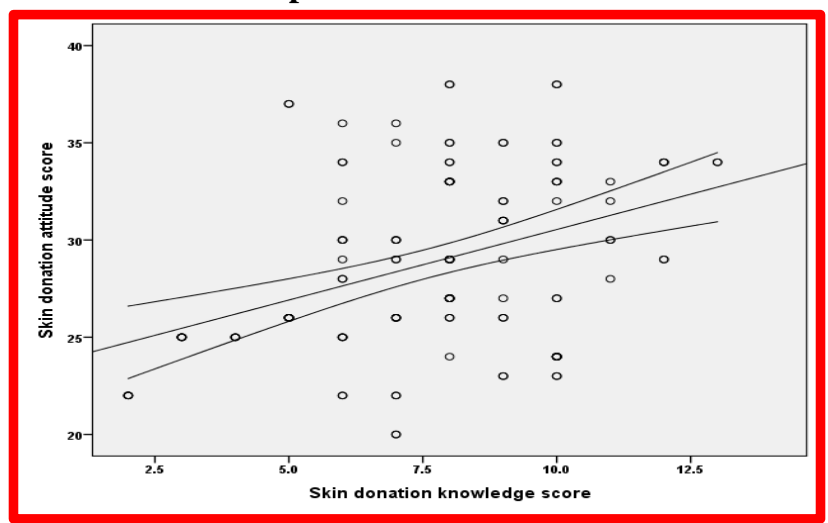




\section{International Journal of Current Science Research and Review}

ISSN: 2581-8341

Volume 04 Issue 06 June 2021

DOI: 10.47191/ijcsrr/V4-i6-02, Impact Factor: 5.825

IJCSRR @ 2021

Www.ijcsrr.org

Fig 6: The scatter diagram illustrates the relationship between awareness and the attitude of Skin Bank

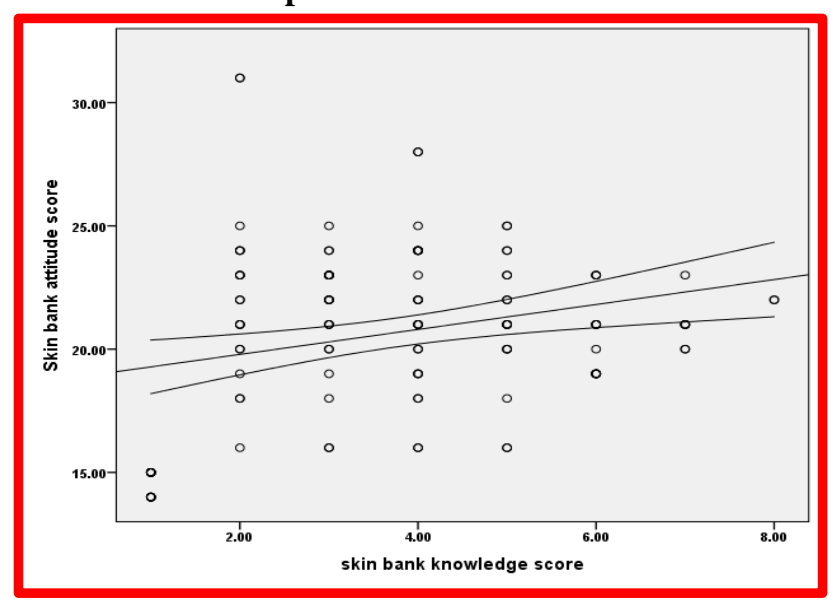

\section{DISCUSSION}

According to the study's findings, barely half of the health care professionals, $51.6 \%$ and less than half (47.5\%), had a somewhat better understanding of skin donation and skin banking. Nonetheless, as per a study in Nigeria (2014), awareness and attitude towards skin donation amongst nurses and doctors were high 78.3 per cent, and they were also aware that skin could be donated from the deceased.[3] Males $86.9 \%$ were more passionate, increased acceptance of skin donation than women $72.5 \%$ and all these findings coincided with Adnang's statement to varying degrees 68 per cent of women had considerably higher acceptance with skin donation over men 32 per cent. Half of the 51.6 per cent of healthcare providers were aware of skin donation from social networks; such results weren't in line with the study conducted by Michel et al., these results were emphasised, extremely good percentage Skin donation is acknowledged by $96.9 \%$ of health care providers. [26] In India, the media is the key source of information exchange $\&$ influences people's perceptions. [27] The knowledge level among study respondents regarding skin donation 58.33 per cent and 7.4 per cent on skin banking was significant at the $(\mathrm{P}=0.03)$ level. The study's findings were supported by a survey carried in Riyadh (2017), which revealed, males 90.3 per cent were more knowledgeable than females with the notion of organ donation after death. They donated skin that used to rehabilitate burnt victims to conquer disfigurement. [10] The majority of study participants were more receptive towards skin donation ( 82.26 per cent), skin bank (83.88 per cent), and professional experience at intensive units, improving the overall view regarding skin donation and willingly giving processes. Human skin transplantation is a complex and sensitive matter because it concerns well being. These findings were recommended in Sweden's research. [28] According to the present study, physical ugliness following donating skin tissue is a major factor opposing skin donation. It was agreed by 64.52 per cent) of study participants and also $(67.74 \%$ ) of health care professionals that funeral service is unattainable. Only $16.13 \%$ consented to motivate and assist their family and the public on skin donation. With both the study in Oyo state, similar findings were inconsistent. Almost the majority of them seem to be happy to give their skin, with only a few claiming deformities as that the reason for the reluctance to tissue donation[29].

In this study, healthcare professionals vowed for organ donation and positively perceived skin donation and skin bank. Some assume that simplifying instruction might influence attitudes. These findings are on par with Esezobor et al. Healthcare workers were likely to donate organs and educate the public about skin donation and skin banking benefits to aid burns and surgical, traumatic victims. [30] According to the present study results, only $22.58 \%$ were ready to volunteer their skin after they die. In opposition to a recent study, Turkish found more than half \% of healthcare workers were enrolled to become organ donors; however, $89.7 \%$ of them declared a willingness to accept the transplant. [31]Finally, health care professionals with much more understanding about skin donation have a favourable and highly correlated attitude towards skin donation $(\mathrm{r}=0.36, \mathrm{p}=0.01)$, implying that increased information about skin donation enhances their perspective on skin donation. In connection to the Taiwan study, an increase in educational standards and the training of the health care providers about various methods of donating organs and owing may create a reasonable opinion. [32] Bilgin has indeed highly recommended that lack of awareness on organ donation impacts willingness among health care workers. [33] Religion is the most influential factor in skin and organ donation; it may advocate the public. [34] As per the conclusions of the Serbian research, spiritual organisation' participation supported and encouraged organ donation 


\section{International Journal of Current Science Research and Review}

ISSN: 2581-8341

Volume 04 Issue 06 June 2021

DOI: 10.47191/ijcsrr/V4-i6-02, Impact Factor: 5.825

IJCSRR@ 2021

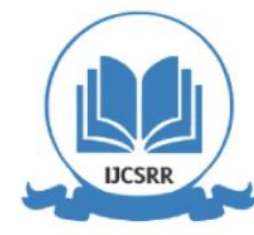

Www.ijcsrr.org

and bequeathing processes. [33] In the current study, most individuals, 75.81 per cent practice Hinduism and therefore have no strong influence on skin donation and skin banking. [33]

\section{RECOMMENDATIONS}

The magnitude and demand for skin donation are high, and it is vital to highlight the importance of providing information on tissue transplantation at the institutional level. Health care professionals could act as mentors to promote awareness. Addressing teenage school and college students on skin donation and conducting school health program at the primary and secondary levels would influence the direction to behaviour and attitude among children, increasing the number of donors in the future. The survivor' awareness movies' sharing experiences could be used to raise awareness.

To draw attention and promote understanding of skin donation amongst this public, healthcare professionals would address immediate surroundings by giving a specific anecdote and commitment. Social support and understanding can be an incredible asset for dealing with the challenges of promoting skin donation.

\section{CONCLUSION}

In this survey, health care professionals' familiarity with skin donation and skin banking is mediocre. These study results strongly suggest a need to deepen understanding during professional training and inform people through health talks and media. A continual educational campaign highlights the fact of organ and skin donation. In the process of skin donation and transplantation, healthcare professionals serve an important. The attitude toward skin donation can affect public opinion and also the choice to donate skins and other organs made by relatives of deceased donors. Hospital and nursing administrators should be actively involved in education programmes to enhance nurses' education and increase awareness about skin donation and skin banking.

\section{ACKNOWLEDGEMENT}

The investigator would like to thank the Director of AIIMS, Bhubaneswar, and the IEC AIIMS, Bhubaneswar, Odisha, India, for granting ethical approval. Dean ESIC Medical College Hospital, SSH, Hyderabad, India, has graciously granted permission to conduct a pilot study. We sincerely thank the Experts for validating the questionnaire used in this study. Our deepest gratitude goes to the study participants and the experts who evaluated the survey.

\section{REFERENCES}

1. Ibrahim M, Randhawa G. Knowledge, Attitudes, and Behavior of Nigerian Students Toward Organ Donation. Transplant Proc 2017;49:1691-7. https://doi.org/10.1016/j.transproceed.2017.04.011.

2. Tognetti L, Pianigiani E, Ierardi F, Mariotti G, Perotti R, Di Lonardo A, et al. Current insights into skin banking: storage, preservation and clinical importance of skin allografts. J Biorepository Sci Appl Med 2017; Volume 5:41-56. https://doi.org/10.2147/bsam.s115187.

3. Michael AI, Ademola SA, Olawoye OA, Iyun AO, Oluwatosin OM. Awareness and attitude of doctors and nurses at a teaching hospital to skin donation and banking. Burns 2014;40:1609-14. https://doi.org/10.1016/j.burns.2014.03.009.

4. Bhansali C, Gandhi G, Sahastrabudhe P, Panse N. Epidemiological study of burn injuries and its mortality risk factors in a tertiary care hospital. Indian J Burn 2017;25:62. https://doi.org/10.4103/ijb.ijb_28_16.

5. Burns : Management and Prevention - n.d. https://www.aimu.us/2016/09/25/burns-management-and-prevention/ (accessed January 31, 2021).

6. Linden PK. History of Solid Organ Transplantation and Organ Donation. Crit Care Clin 2009;25:165-84. https://doi.org/10.1016/j.ccc.2008.12.001.

7. Barker CF, Markmann JF. Historical overview of transplantation. Cold Spring Harb Perspect Med 2013;3. https://doi.org/10.1101/cshperspect.a014977.

8. Narayan RP. Development of tissue bank. Indian J Plast Surg 2012;45:396-402. https://doi.org/10.4103/09700358.101326.

9. Burns | National Health Portal Of India n.d. https://www.nhp.gov.in/disease/skin/burns (accessed January 31, 2021).

10. Gelidan AG. Awareness and attitude of general population regarding allograft skin donation in Riyadh, Saudi Arabia: Cross-sectional study. Burns 2020;46:1700-6. https://doi.org/10.1016/j.burns.2020.04.002. 


\section{International Journal of Current Science Research and Review}

ISSN: 2581-8341

Volume 04 Issue 06 June 2021

DOI: 10.47191/ijcsrr/V4-i6-02, Impact Factor: 5.825

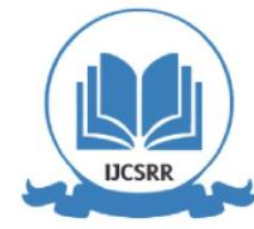

www.ijesrr.org

11. Kumar V. Skin bank - the need of hour for burn treatment. Indian J Burn 2018;26:1. https://doi.org/10.4103/ijb.ijb_4_19.

12. LTMGH $\mid$ Skin Donation and Skin Banking n.d. http://www.ltmgh.com/FrontView/inner.aspx?Mkey=ODYz\&lKey=NA== (accessed February 2, 2021).

13. Keswani SM, Mishra MG, Karnik S, Dutta S, Mishra M, Panda S, et al. Skin banking at a regional burns centre-The way forward. Burns 2018;44:870-6. https://doi.org/10.1016/j.burns.2017.11.010.

14. Cadaver skin donation and skin bank Gore M - Indian J Burns n.d. https://www.ijburns.com/article.asp?issn=0971653X; year $=2017$; volume $=25$; issue $=1$; spage $=3$; epage $=5$; aulast=Gore (accessed February 2, 2021).

15. Panse N, Panse S, Jhingan M, Kulkarni P, Gandhi G, Kulkarni Y. Knowledge and awareness of skin donation in medical students: Overcoming the barriers. Indian J Plast Surg 2014;47:141-3. https://doi.org/10.4103/0970-0358.129652.

16. Bhate-Deosthali P, Lingam L. Gendered pattern of burn injuries in India: a neglected health issue. Reprod Health Matters 2016;24:96-103. https://doi.org/10.1016/j.rhm.2016.05.004.

17. Burns n.d. https://www.who.int/news-room/fact-sheets/detail/burns (accessed February 2, 2021).

18. Vlaisavljevic Z, Jankovic S, Maksimovic N, Culafic M, Stulic M, Milovanovic T, et al. Attitudes of Nurses Toward Organ Donation in Serbia. Transplant Proc 2020;52:673-9. https://doi.org/10.1016/j.transproceed.2020.01.031.

19. Hoy H, Alexander S, Frith KH, Ng YC. The effect of transplant education on nurses attitudes toward organ donation and advocacy for transplantation: Instrument development. Prog Transplant 2017;27:175-9.

https://doi.org/10.1177/1526924817699961.

20. Esezobor CI, Disu E, Oseni SBA. Attitude to organ donation among healthcare workers in Nigeria. Clin Transplant 2012;26. https://doi.org/10.1111/ctr.12032.

21. Kocaay AF, Celik SU, Eker T, Oksuz NE, Akyol C, Tuzuner A. Brain Death and Organ Donation: Knowledge, Awareness, and Attitudes of Medical, Law, Divinity, Nursing, and Communication Students. Transplant. Proc., vol. 47, Elsevier USA; 2015, p. 1244-8. https://doi.org/10.1016/j.transproceed.2015.04.071.

22. ICU Nurses' Knowledge, Attitude, and Practice Towards their Role in the Organ Donation Process from Brain-Dead Patients and Factors Influencing it in Iran - PubMed n.d. https://pubmed.ncbi.nlm.nih.gov/26306156/ (accessed February $2,2021)$.

23. S. G. M, Subramanian M, Atmakuri SA, S. T, Bera P, J. N. A study on knowledge, attitude and practice regarding organ donation and transplantation among final year health science students in Bengaluru, Karnataka, India. Int J Community Med Public Heal 2018;5:1529. https://doi.org/10.18203/2394-6040.ijcmph20181230.

24. Madhavi KVP, Paruvu K. Menstrual hygiene and practices among adolescent girls in rural Visakhapatnam: a crosssectional study. Int J Community Med Public Heal 2018;6:432. https://doi.org/10.18203/2394-6040.ijcmph20185284.

25. Pianigiani E, Ierardi F, Di Simplicio FC, Andreassi A. Skin bank organization. Clin Dermatol 2005;23:353-6. https://doi.org/10.1016/j.clindermatol.2004.07.016.

26. Ali NF, Qureshi A, Jilani BN, Zehra N. Knowledge and ethical perception regarding organ donation among medical students. BMC Med Ethics 2013;14:38. https://doi.org/10.1186/1472-6939-14-38.

27. Gore MA, De AS. Deceased donor skin allograft banking: Response and utilisation. Indian J Plast Surg 2010;43:S114. https://doi.org/10.4103/0970-0358.70732.

28. Sanner M. A Swedish survey of young people's views on organ donation and transplantation. Transpl Int 2002;15:641-8. https://doi.org/10.1007/s00147-002-0474-1.

29. Michael AI, Ademola SA, Olawoye OA, Iyun AO, Oluwatosin OM. Awareness and attitude of doctors and nurses at a teaching hospital to skin donation and banking. Burns 2014;40:1609-14. https://doi.org/10.1016/j.burns.2014.03.009.

30. Esezobor CI, Disu E, Oseni SBA. Attitude to organ donation among healthcare workers in Nigeria. Clin Transplant 2012;26:E612-6. https://doi.org/10.1111/ctr.12032.

31. Günay O, Sağiroğlu M, Günay O, Balci E. A r c h i v e o f S I D International Journal of Organ Transplantation Medicine Attitudes of Turkish Medical and Law Students towards the Organ Donation. vol. 6. INTERNATIONAL JOURNAL OF ORGAN TRANSPLANTATION MEDICINE ; 2015.

32. Wang TH, Lee PC, Chiang YJ. Taiwan's organ donation and transplantation: Observation from national registry point of view. J Formos Med Assoc 2017;116:649-51. https://doi.org/10.1016/j.jfma.2017.02.017. 


\section{International Journal of Current Science Research and Review}

ISSN: 2581-8341

Volume 04 Issue 06 June 2021

DOI: 10.47191/ijcsrr/V4-i6-02, Impact Factor: 5.825

IJCSRR @ 2021

www.ijesrr.org

33. Bilgin N, Akgun HS. A focus on health care professionals in organ donation: A cross-sectional survey. Transplant. Proc., vol. 34, Transplant Proc; 2002, p. 2445-7. https://doi.org/10.1016/S0041-1345(02)03172-X.

34. Randhawa G, Neuberger J. Role of Religion in Organ Donation - Development of the United Kingdom Faith and Organ Donation Action Plan. Transplant Proc 2016;48:689-94. https://doi.org/10.1016/j.transproceed.2015.10.074.

Cite this Article: Mrs. Serma Subathra Arunachalam, Dr. Asha P Shetty, Dr. Sanjay K Giri, Dr. Shankar Shanmugam Rajendran, Mr. HariKrishnan Eswaran (2021). Understanding and Perceptions of Skin Donation and Skin Banking Among Health Care Professionals - Tertiary Care Centre in Eastern India. International Journal of Current Science Research and Review, 4(6), 487-498 